\title{
Profile of panobinostat and its potential for treatment in solid tumors: an update
}

This article was published in the following Dove Press journal:

OncoTargets and Therapy

14 November 2013

Number of times this article has been viewed

\section{Madhurima Anne' \\ Daniel Sammartino ${ }^{2}$ \\ Myra F Barginear ${ }^{\prime}$ \\ Daniel Budman'}

'Monter Cancer Center, Hofstra North Shore-LIJ School of Medicine, Lake Success, NY, USA; ${ }^{2}$ Department of Medicine, Hofstra North Shore-LIJ School of Medicine, Lake Success, NY, USA
Correspondence: Madhurima Anne Monter Cancer Center, Hofstra North Shore LIJ School of Medicine, 450 Lakeville Road, New Hyde Park, NY I I042, USA $\mathrm{Tel}+$ I 5165248179

Email madhurima.anne@gmail.com
Abstract: The histone deacetylase (HDAC) inhibitors have emerged as novel therapies for cancer. Panobinostat (LBH 589, Novartis Pharmaceuticals) is a pan-deacetylase inhibitor that is being evaluated in both intravenous and oral formulations across multiple tumor types. Comparable to the other HDACs, panobinostat leads to hyperacetylation of histones and other intracellular proteins, allowing for the expression of otherwise repressed genes, leading to inhibition of cellular proliferation and induction of apoptosis in malignant cells. Panobinostat, analogous to other HDAC inhibitors, also induces apoptosis by directly activating cellular death receptor pathways. Preclinical data suggests that panobinostat has inhibitory activity at nanomolar concentrations and appears to be the most potent clinically available HDAC inhibitor. Here we review the current status of panobinostat and discuss its role in the treatment of solid tumors.

Keywords: panobinostat, LBH589, histone deacetylase inhibitor, solid tumors

\section{Introduction}

The important role of epigenetic changes in the development of cancer has recently been recognized. ${ }^{1}$ The two main epigenetic modifications are DNA methylation and posttranslational histone modifications, such as acetylation, methylation, and phosphorylation. ${ }^{1}$ The acetylation of lysine residues on histones leads to an open chromatin state that allows for gene transcription whereas deacetylation leads to a condensed chromatin state and gene silencing. Histone deacetylases (HDACs) are thought to be dysregulated in malignancy, leading to aberrant gene repression and the survival of malignant cells. ${ }^{2}$ In this setting, the HDAC inhibitors have been developed as potentially effective cancer therapies. Currently, vorinostat and romidepsin are the only Food and Drug Administration (FDA)-approved HDAC inhibitors; they have been approved for treatment of cutaneous T-cell lymphoma. ${ }^{2}$ Panobinostat (Figure 1) is an investigational pan-deacetylase inhibitor (pan-DACi) that has demonstrated greater inhibitory activity in vitro against all Class I, II, and IV HDAC enzymes than the current FDA-approved HDACs. ${ }^{3}$

Preclinical studies have shown panobinostat to have antitumor activity in several hematologic malignancies, including acute myeloid leukemia, chronic myeloid leukemia, Hodgkin lymphoma, multiple myeloma, and non-Hodgkin lymphoma (NHL), specifically cutaneous T-cell lymphoma (CTCL). ${ }^{4}$ Given the promising preclinical activity of panobinostat in hematologic malignancies, its potential efficacy is being evaluated both as a single agent and also in combination with chemotherapeutic, biologic, and small molecule inhibitor therapies for solid tumors. 


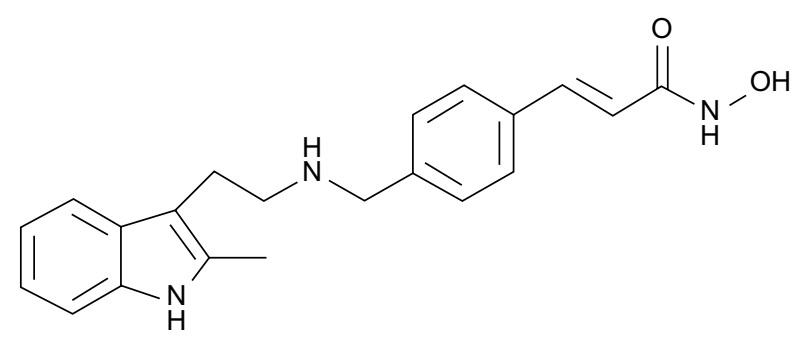

Figure I Structure of panobinostat.

Note: The systematic (IUPAC) name is (2E)-N-hydroxy-3-[4-(\{[2-(2-methyl-IHindol-3-yl)ethyl]amino\}methyl)phenyl]acrylamide.

\section{Panobinostat: mechanism of action}

HDAC enzymes regulate transcription and other cellular processes by removing acetyl groups from target proteins. ${ }^{5}$ HDACs can be classified as either zinc-dependent HDACs (Class I, Class II, and Class IV) or the zinc-independent, nicotinamide adenine dinucleotide (NAD)-dependent Class III sirtuin enzymes (Table 1). ${ }^{3}$ Class I HDACs, which are located within the cell nucleus, remove acetyl groups from lysine residues on histones, thus leading to a condensed chromatin state and gene silencing. ${ }^{1}$ They play a role in cell survival and proliferation through interaction with transcription factor p53. ${ }^{6}$ Class II HDACs shuttle between the cytoplasm and nucleus and act on nonhistone proteins. HDAC6, a member of Class IIb HDAC mainly localized to the cytoplasm, deacetylates heat shock protein 90 (Hsp90), which is a chaperone protein involved in protein stabilization. ${ }^{6,7}$ HDAC6 plays a role in the transport of misfolded proteins to aggresomes for lysosomal degradation. ${ }^{8}$ Inhibition of the aggresome pathway in tumor cells results in the accumulation of polyubiquinated proteins, leading to endoplasmic reticulum stress, inducing apoptosis. ${ }^{8}$ HDAC6 also downregulates pro-apoptotic factor HR23B, which plays a role in shuttling ubiquinated proteins to proteasomes for degradation. ${ }^{9}$ HDAC inhibitors cause apoptosis in cells with high expression of HR23B while also causing autophagy in cells with low expression of HR23B. HR23B has been identified in CTCL cells as a predictive biomarker for response to treatment with panobinostat. ${ }^{10}$

Table I Classification of HDACs

\begin{tabular}{ll}
\hline Zinc-dependent & Zinc-independent \\
\hline Class I & Class III \\
HDACI, HDAC2, HDAC3, HDAC8 & Sirtuins I-7 \\
Class II & \\
Class Ila: HDAC4, HDAC5, HDAC7, HDAC9 \\
Class Ilb: HDAC6, HDACI0 \\
Class IV \\
HDACII \\
\hline
\end{tabular}

Abbreviation: HDAC, histone deacetylase.
HDAC inhibitors do not inhibit Class III HDACs. Class I-specific inhibitors include mocetinostat (MGCD0103), entinostat (MS275), and romidepsin. Class I- and IIa-specific inhibitors include butyrate and valproate. Pan-DACis inhibit Classes I, II, and IV, and include panobinostat, vorinostat, and belinostat (PXD101) (Figure 2). ${ }^{11}$ Pan-DACis have also been shown to decrease angiogenesis, induce apoptosis and cell cycle arrest, decrease tumor cell motility, and decrease oncoprotein expression through effects on nonhistone protein targets. ${ }^{12}$ Such targets include transcription factors that regulate gene expression, including $\mathrm{p} 53, \mathrm{NF}-\mathrm{kB}$ and $\mathrm{E} 2 \mathrm{~F} 1$, as well as decreased oncoprotein expression of BCR-Abl and HER2 (human epidermal growth factor receptor 2). Other targets include $\mathrm{Ku} 70$, which regulates DNA repair, and alphatubulin, which regulates the cellular cytoskeleton, as well as Hsp90 (Figure 3). ${ }^{3,11}$ HDAC inhibitors are also thought to sensitize malignant cells to tumor necrosis factor-related apoptosis, inducing ligand-mediated apoptosis through degradation of the anti-apoptotic factor, c-FLIP. ${ }^{11,13}$

\section{Panobinostat pharmacology}

Panobinostat is currently under development in intravenous and oral forms for use across a range of tumor types. In vitro studies have demonstrated potent inhibitory activity against Class I, II, and IV HDAC enzymes, even at nanomolar $\mathrm{LD}_{90}$ (concentration needed for $90 \%$ cell death, range $14-541 \mathrm{nM}){ }^{3}$ In studies using enzymatic assays, panobinostat $\mathrm{IC}_{50}$ (concentration needed for $50 \%$ inhibition) values were $<13.2 \mathrm{nM}$ for all Class I, II, and IV HDAC enzymes, except HDAC4, HDAC7, and HDAC8, all of which had $\mathrm{IC}_{50}$ in the mid-nanomolar range. ${ }^{3}$ Panobinostat $\mathrm{IC}_{50}$ values were lower than those for vorinostat, belinostat, and mocetinostat. Panobinostat had at least ten-fold greater potency when compared with vorinostat. ${ }^{4}$

Panobinostat has unique cancer type specific cytotoxicity, which has been demonstrated in vitro. ${ }^{3}$ Solid tumor cells, such as breast and pancreas require higher $\mathrm{LD}_{90}$ for cytotoxicity $(306-541 \mathrm{nM})$ than hematological cell lines $(14-57.5 \mathrm{nM}){ }^{3}$ Toxicity to normal human cell lines occurred at much greater $\mathrm{LD}_{90}$ (values $>5 \mu \mathrm{M}$ ) than concentrations required to achieve toxicity in malignant cells. ${ }^{3}$

Analysis of multiple Phase I and II studies demonstrated panobinostat pharmacokinetics to be linear. ${ }^{14}$ The exact metabolism and clearance mechanism of panobinostat, a hydroxamic acid derivative, has not as yet been elucidated. Preclinical studies suggest that the mechanism of clearance is complex, involving reduction, hydrolysis, and carbon group shortening of the hydroxamic acid group. ${ }^{15}$ Additional pathways including glucuronidation and mono-oxygenation of the ethyl-methyl indole moiety have been implicated. 


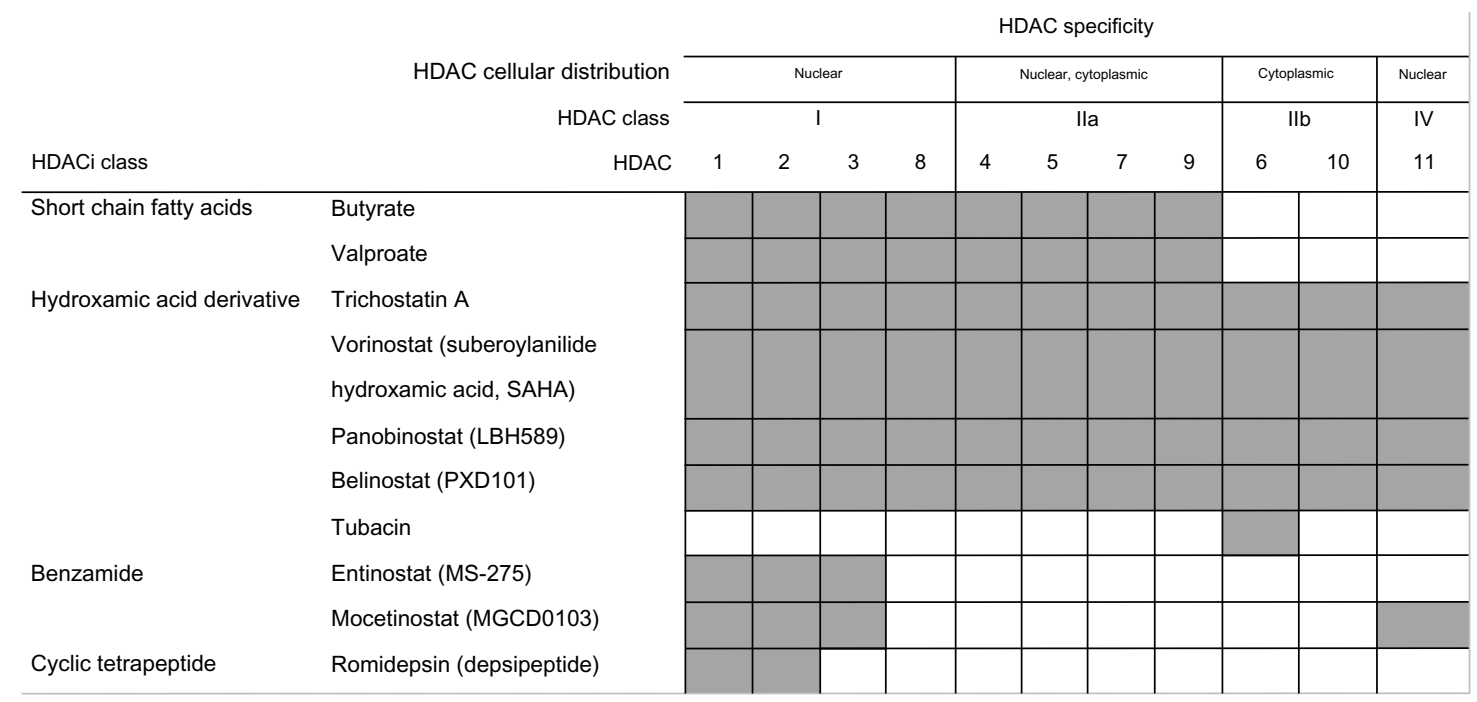

Figure 2 Classes, targets and cellular distribution of HDAC inhibitors.

Note: Reprinted with permission from Springer, and Dickinson M, Johnstone RW, Prince HM. Histone deacetylase inhibitors: potential targets responsible for their anticancer effect. Invest New Drugs. 2010;28(Suppl I):S3-S20." With kind permission from Springer Science and Business Media.

Abbreviation: HDAC, histone deacetylase; $\mathrm{HDACi}$, histone deacetylase inhibitor.

A study using ${ }^{14} \mathrm{C}$-radiolabeled panobinostat at an oral dose of $20 \mathrm{mg}$ in patients with advanced solid tumors and hematologic malignancies measured total radioactivity in blood and metabolites in urine and feces on days one to eight post-administration. Elimination through the urinary and fecal routes was relatively equal, contributing to $40.6 \%$ and $54.3 \%$, respectively, of the total dose administered. Of the 77 metabolites detected, 40 were detected in circulating plasma and $1.1 \%-2.4 \%$ of administered drug was detected unchanged in the urine. ${ }^{15}$

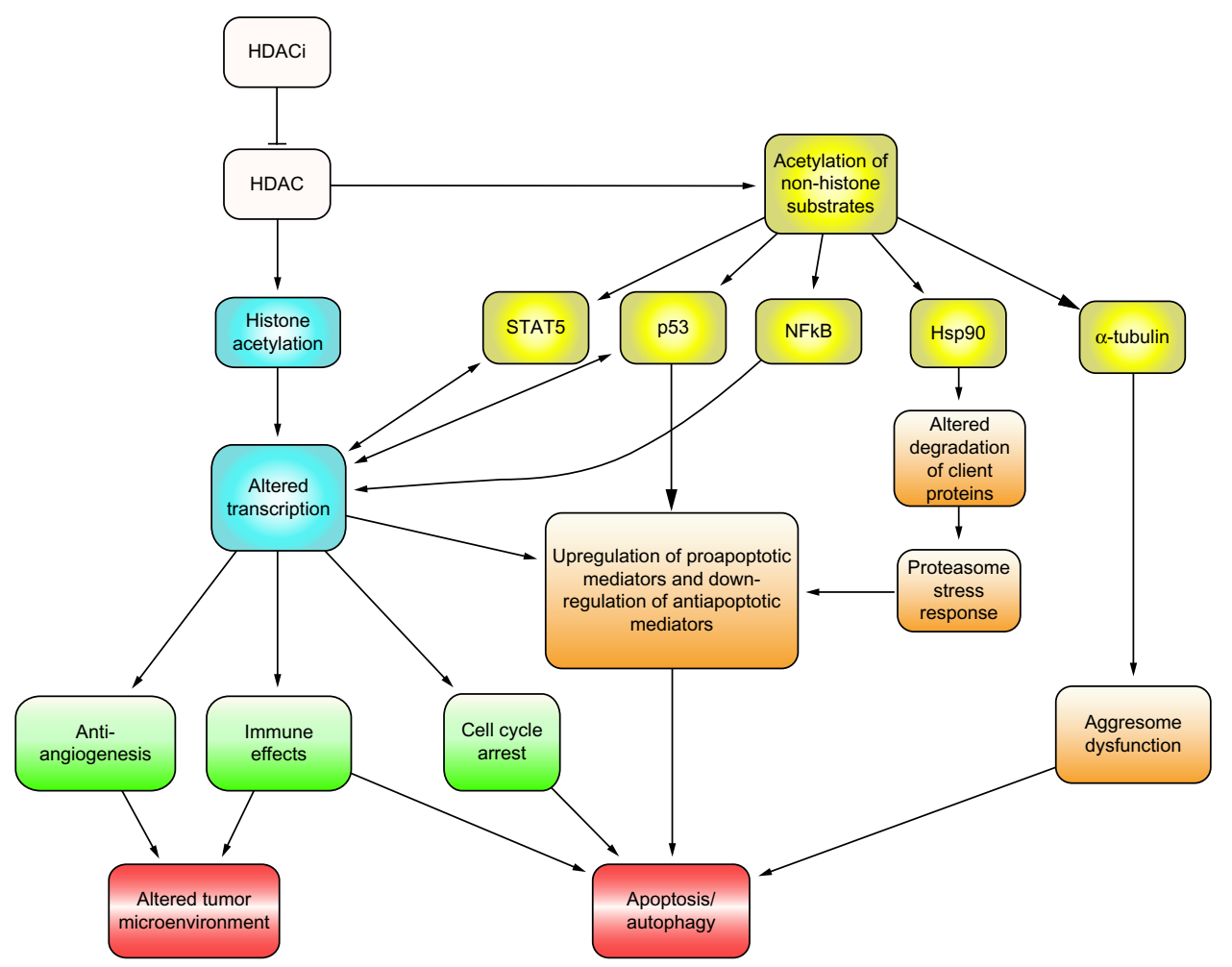

Figure 3 Targets and downstream effects of HDAC inhibitors.

Note: Reprinted with permission from Springer, and Dickinson M, Johnstone RW, Prince HM. Histone deacetylase inhibitors: potential targets responsible for their anticancer effect. Invest New Drugs. 2010;28(Suppl I):S3-S20.II With kind permission from Springer Science and Business Media.

Abbreviations: HDACi, histone deacetylase inhibitor; HDAC, histone deacetylase; Hsp90, heat shock protein 90; STAT5, signal transducer and activator of transcription 5; p53, tumor suppressor protein 53; NFkB, nuclear factor kappa-light-chain-enhancer of activated B cells. 
In a Phase I study of 36 patients with solid tumors, the effect of food on the half-life and bioavailability of panobinostat was studied. ${ }^{16}$ Three different prandial states were evaluated, including: (1) fasting (10 hours prior to and four hours post-administration of panobinostat); (2) after high-fat breakfast (administration within 30 minutes after consumption of meal); and (3) after regular breakfast (administration within 60 minutes after consumption of meal). No significant association with food intake was found when pharmacokinetic parameters were measured during these states, with unchanged oral bioavailability (similar area under the curve [AUC] when interpatient variability was accounted for) in fasting as well as in different prandial states. ${ }^{16}$

Panobinostat is metabolized primarily by cytochrome P450, CYP3A4, along with CYP2D6, and CYP2C19. ${ }^{17}$ The strong CYP3A4 inhibitor, ketoconazole, was coadministered with panobinostat and demonstrated an increase in $\mathrm{C}_{\max }$ (maximum concentration achieved after administration) and AUC of panobinostat of 1.6- and 1.8-fold respectively, without significant change in $\mathrm{T}_{\max }$ (time to reach maximum concentration after administration) or half-life. ${ }^{17}$ Monitoring for potential toxicities is needed if panobinostat is coadministered with a CYP3A4 inhibitor. A Phase I trial is underway to evaluate the effect of various degrees of hepatic dysfunction on the pharmacokinetics of panobinostat.

The effect of renal dysfunction on the pharmacokinetics of panobinostat is also being evaluated in a Phase I study, and preliminary results have been reported. ${ }^{18}$ Panobinostat was administered at a dose of $30 \mathrm{mg}$ orally three times weekly with varying degrees of renal dysfunction (mild, moderate or severe according to 24-hour creatinine clearance). Plasma and urine concentrations of panobinostat assessed by liquid chromatography tandem mass spectrometry following administration did not suggest higher drug exposures $\left(\mathrm{C}_{\max }, \mathrm{AUC}\right.$, half-life) with increasing severity of renal dysfunction. ${ }^{18}$ A formal algorithm for dosing in patients with significant renal dysfunction has not yet been developed.

\section{Safety and tolerability of panobinostat in the clinical setting}

Several Phase I and Phase II studies have been performed to evaluate the pharmacokinetics, maximum tolerated dose (MTD), and the safety and tolerability of panobinostat in hematologic malignancies and solid tumors. Panobinostat appears to be well tolerated, with the most common side effects being fatigue, nausea, vomiting, and diarrhea. Early Phase I studies of intravenous panobinostat administered daily found dose-limiting toxicity (DLT) of electrocardiographic
QTc prolongation; hence, subsequent studies have utilized an intermittent dosing schedule. ${ }^{19}$ Oral dosing of panobinostat has also been studied in various schedules. In an analysis performed on pooled data from eight completed or ongoing Phase I or Phase II trials using panobinostat, thrombocytopenia was the most common laboratory abnormality of any grade, as well as the most common DLT. ${ }^{20}$ Of note, the MTD in hematologic malignancies appears to be two- to three-fold higher than that in solid tumors. Table 2 summarizes the pharmacokinetic data along with DLTs and the most common CTCAE (Common Terminology Criteria for Adverse Events) from Phase I studies performed in advanced solid tumors and advanced NHL.

A Phase I pharmacokinetic and pharmacodynamic study evaluated intravenous administration of panobinostat at three dose levels weekly in advanced solid tumors and NHL (Table 2). ${ }^{21}$ The MTD in this intravenous weekly schedule was $20 \mathrm{mg} / \mathrm{m}^{2}$. One DLT of grade 4 thrombocytopenia was found at this dose. In addition, QTcF (QT interval corrected for heart rate using Fridericia's formula) prolongation occurred at $20 \mathrm{mg} / \mathrm{m}^{2}$. Common adverse events (AE) included transient thrombocytopenia $(9.1 \%)$, anemia $(9.1 \%)$, and fatigue $(4.5 \%) .^{21}$

In a Phase Ia/II dose escalation study in patients with advanced hematologic malignancies, the most common AEs included diarrhea (58\%), nausea (53.4\%), and fatigue (52.8\%) (Table 2). ${ }^{22}$ Grade 3 QTcF prolongation was observed at $80 \mathrm{mg}$. Thrombocytopenia was the most common DLT. MTD differed by malignancy; the recommended dose was $60 \mathrm{mg}$ in patients with leukemia and myeloid disorders, whereas for lymphoma and myeloma the recommended dose was $40 \mathrm{mg}$ weekly and $60 \mathrm{mg}$ biweekly. ${ }^{22}$

A Phase I dose escalation study of oral panobinostat in patients with advanced solid tumors and non-Hodgkin lymphoma showed a MTD of $20 \mathrm{mg}$ (Table 2). ${ }^{23}$ In this study, the DLT was grade 3 and 4 diarrhea and thrombocytopenia, respectively, at $30 \mathrm{mg}$, and grade 3 fatigue at $20 \mathrm{mg}$. The most common AEs were anorexia, nausea, fatigue, diarrhea and transient thrombocytopenia.

A similar Phase I dose escalation trial in Japanese patients with advanced CTCL, as well as in solid tumor patients, showed that a dose of $20 \mathrm{mg}$ daily was well tolerated (Table 2). ${ }^{24} \mathrm{In}$ this study, anemia $(n=1)$ and thrombocytopenia $(n=2)$ were the most common grade 4 AEs. The most common AE were diarrhea and nausea (both, 76.9\%) and transient thrombocytopenia (92.3\%). Absolute QT prolongation ( $>480 \mathrm{~ms}$ ) was not observed though prolongation $>60 \mathrm{~ms}$ from baseline was observed in two patients without symptoms. 


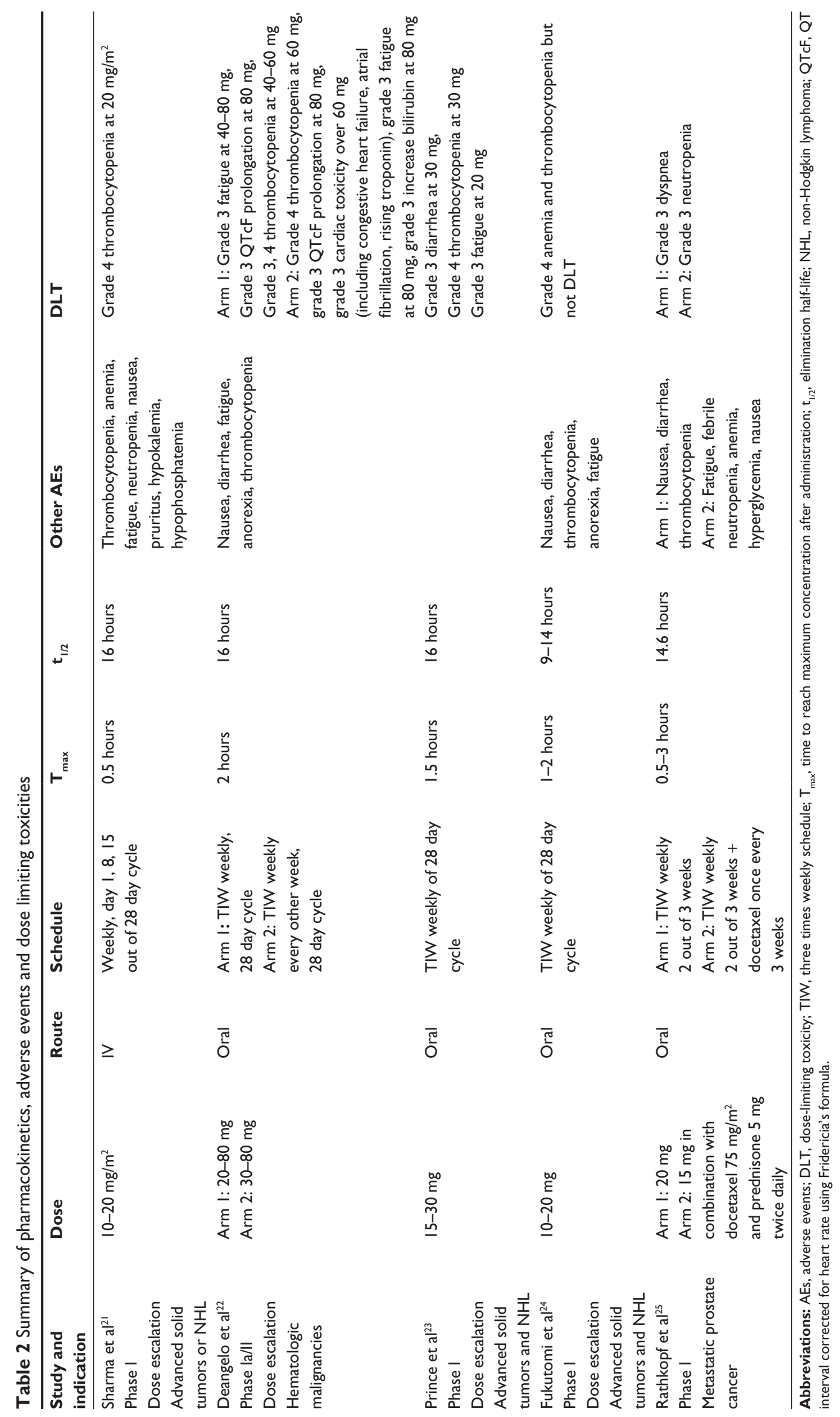


Another Phase I trial in patients with castrationresistant metastatic prostate cancer evaluated panobinostat alone as compared with the combination with docetaxel $75 \mathrm{mg} / \mathrm{m}^{2}$ (Table 2). ${ }^{25}$ In this study, the DLT was dyspnea in one patient in the single agent arm (arm 1) and neutropenia in the combination arm (arm 2) with docetaxel. The most common AEs were nausea (75\%), diarrhea (50\%), and thrombocytopenia (50\%) for arm 1, and neutropenia $(87.5 \%)$, fatigue $(62.5 \%)$, anemia $(62.5 \%)$, and nausea $(62.5 \%)$ for arm 2 .

\section{Panobinostat in solid tumors}

In what follows, we review preclinical (summarized in Table 3) and clinical (summarized in Table 4) studies of panobinostat in specific tumor types.

\section{Breast cancer}

In vitro studies by Tate et $\mathrm{al}^{26}$ have shown that triple negative breast cancer cell lines incubated with panobinostat have increased histone acetylation as well as drug dose-dependent decrease in cell proliferation. Additionally, in vivo studies of panobinostat in triple negative breast cancer mice models, at a concentration of $10 \mathrm{mg} / \mathrm{kg} /$ day for 5 days per week, resulted in significant decreases in tumor volume (Table 3 ). ${ }^{26}$ Other preclinical studies in triple negative breast cancer have found similar results, as seen with a study of co-treatment of panobinostat and chloroquine, an autophagy inhibitor, which demonstrated that this drug combination reduced tumor burden and increased survival in triple negative breast cancer xenografts. ${ }^{27}$

Panobinostat was found to have synergistic effects with docetaxel, doxorubicin, and gemcitabine in both hormone receptor rich and poor cell lines. ${ }^{28}$ Bortezomib has also been shown to enhance synergism of panobinostat and gemcitabine. Triplet combinations with panobinostat and doxorubicin/carboplatin or gemcitabine/carboplatin have been shown to be extremely potent in cell lines. ${ }^{28}$

In a Phase I study, patients who had progressed on treatment with trastuzumab were treated with either intravenous panobinostat, or oral panobinostat in combination with trastuzumab. ${ }^{29}$ Preliminary analysis of 25 patients revealed that eight patients had stable disease, with two of these patients having 29\% tumor reduction (Table 4).

A Phase I study is currently underway evaluating panobinostat in combination with letrozole. ${ }^{30}$ Letrozole was administered at a dose of $2.5 \mathrm{mg}$ daily along with panobinostat at a dose of either $20 \mathrm{mg}$ or $30 \mathrm{mg}$ orally three times weekly. To date, results from 12 enrolled patients have been reported. One patient at $30 \mathrm{mg}$ has a confirmed partial response. No DLTs were observed at a dose of $20 \mathrm{mg}$, but the DLT of thrombocytopenia was observed at the dose of $30 \mathrm{mg}$. Another Phase I study is underway evaluating panobinostat in combination with capecitabine with or without lapatinib.

Table 3 Preclinical studies of panobinostat

\begin{tabular}{|c|c|c|}
\hline Cancer & Study & Results \\
\hline TNBCA xenografts ${ }^{26}$ & $\begin{array}{l}\text { Panobinostat } 10 \mathrm{mg} / \mathrm{kg} \text { IP injections daily } \times \\
5 \text { days } / \text { week versus placebo }\end{array}$ & $\begin{array}{l}3-4 \text { fold reduction in tumor volume compared } \\
\text { to control at } 4 \text { I days }\end{array}$ \\
\hline CRC xenografts ${ }^{40}$ & $\begin{array}{l}\text { Panobinostat } 2.5 \mathrm{mg} / \mathrm{kg} \text { IP injections daily } \times \\
5 \text { days/week versus lapatinib } 30 \mathrm{mg} / \mathrm{kg} \text { oral } \\
\text { twice daily versus the combination }\end{array}$ & $\begin{array}{l}\text { Panobinostat monotherapy: } 23.8 \% \text { reduction TV } \\
\text { Lapatinib monotherapy: } 4.1 \% \text { reduction TV } \\
\text { Combination: } 49.8 \% \text { reduction TV }\end{array}$ \\
\hline HCC xenografts ${ }^{46}$ & $\begin{array}{l}\text { Panobinostat } 15 \mathrm{mg} / \mathrm{kg} \text { IP injections daily } \times \\
5 \text { Sorafenib } 30 \mathrm{mg} / \mathrm{kg} \text { daily } \times 7 \\
\text { Combination panobinostat } 7.5 \mathrm{mg} / \mathrm{kg} \text { daily } \times \\
5+\text { sorafenib } 30 \mathrm{mg} / \mathrm{kg} \text { daily } \times 7\end{array}$ & $\begin{array}{l}\text { Delay in tumor growth observed in } 58.3 \% \text { in } \\
\text { combination group, } 42.9 \% \text { in panobinostat } \\
\text { monotherapy and } 10 \% \text { in sorafenib monotherapy, } \\
\text { and } 8.3 \% \text { in control group }\end{array}$ \\
\hline GIST xenografts ${ }^{47}$ & $\begin{array}{l}\text { Control versus panobinostat } 10 \mathrm{mg} / \mathrm{kg} \\
\text { IP daily, versus imatinib } 150 \mathrm{mg} / \mathrm{kg} \text { po bid } \\
\text { versus combination }\end{array}$ & $\begin{array}{l}\text { Control group tumors increased } 2 \text { fold; } \\
\text { panobinostat alone } 25 \% \text { reduction tumor, } \\
\text { imatinib alone } 62 \% \text { reduction tumor, combination } \\
73 \% \text { reduction tumor }\end{array}$ \\
\hline ATC xenografts ${ }^{52}$ & $\begin{array}{l}\text { Panobinostat at } 10 \mathrm{mg} / \mathrm{kg}, 20 \mathrm{mg} / \mathrm{kg} \text {, } \\
30 \mathrm{mg} / \mathrm{kg} I \mathrm{P} \text { injections } 5 \text { days } / \text { week } \times 21 \text { days }\end{array}$ & $\begin{array}{l}\text { At } 20 \mathrm{mg} / \mathrm{kg} \text { : significant reduction tumor growth, } \\
\mathrm{Ki} 67\end{array}$ \\
\hline $\mathrm{SCCHN}$ xenografts ${ }^{56}$ & $\begin{array}{l}\text { Panobinostat } 30 \mathrm{mg} / \mathrm{kg} \text { IP injection daily versus } \\
\text { BGT226 } 10 \mathrm{mg} / \mathrm{kg} \text { po daily versus } \\
\text { BEZ235 } 30 \mathrm{mg} / \mathrm{kg} \text { po daily versus } \\
\text { BKMI20 } 7.5 \mathrm{mg} / \mathrm{kg} \text { po daily versus } \\
\text { panobinostat + each of above } 3 \text { drugs }\end{array}$ & $\begin{array}{l}\text { Treatment with BCT226, BEZ235, BKMI } 20 \\
\text { each more effective than combination with } \\
\text { panobinostat or with panobinostat monotherapy }\end{array}$ \\
\hline
\end{tabular}

Abbreviations: TNBCA, triple negative breast cancer; CRC, colorectal cancer; HCC hepatocellular cancer; ATC, anaplastic thyroid cancer; SCCHN, squamous cell cancer of head and neck; GIST, gastrointestinal stromal tumors; IP, intraperitoneal; TV, tumor volume, po, per oral; bid, twice daily. 
Table 4 Summary of panobinostat studies in solid tumors

\begin{tabular}{|c|c|c|c|c|c|c|}
\hline Disease & Study & Dosage & $\mathbf{N}$ & Efficacy & Grade 3-4 AE & Ref \\
\hline $\begin{array}{l}\text { HER + metastatic } \\
\text { breast cancer }\end{array}$ & Phase I & $\begin{array}{l}\text { Arm I: Panobinostat I0-20 mg/m } / \mathrm{m}^{2} \text { day I, } \\
8 \text { every } 2 \text { I days + trastuzumab IV weekly } \\
\text { ( } 4 \mathrm{mg} / \mathrm{kg} \text { load then } 2 \mathrm{mg} / \mathrm{kg} / \text { week) or } \\
\text { Arm 2: Panobinostat I5-40 mg po } \\
\text { TIW + trastuzumab IV weekly } \\
(4 \mathrm{mg} / \mathrm{kg} \text { load then } 2 \mathrm{mg} / \mathrm{kg} / \text { week })\end{array}$ & 25 & $\begin{array}{l}8 \text { SD }(2 \text { with liver } \\
\text { metastases had } 29 \% \text { tumor } \\
\text { reduction })\end{array}$ & $\begin{array}{l}\text { Thrombocytopenia, } \\
\text { neutropenia, diarrhea, } \\
\text { pyrexia, hyperkalemia, } \\
\text { dyspnea, leucopenia, } \\
\text { tachycardia }\end{array}$ & 29 \\
\hline $\begin{array}{l}\text { Small cell lung } \\
\text { cancer }\end{array}$ & Phase II & $\begin{array}{l}\text { Panobinostat } 20 \mathrm{mg} / \mathrm{m}^{2} \mathrm{IV} \text { day I, } \\
8 \text { every } 2 \mathrm{I} \text { days }\end{array}$ & 21 & $\begin{array}{l}3 \text { SD and } 2 \text { patients with } \\
\text { response: } 30 \% \text { decrease } \\
\text { in tumor }\end{array}$ & Hypertension $(\mathrm{n}=\mathrm{I})$ & 35 \\
\hline $\begin{array}{l}\text { High grade } \\
\text { gliomas }\end{array}$ & Phase I & $\begin{array}{l}\text { Arm I: Panobinostat } 20 \mathrm{mg} \text { po weekly, } \\
\text { TIW for } 4 \text { weeks + bevacizumab } \\
\text { I0 mg/kg IV every other week } \times 2 \\
\text { (day I, day I5) } \\
\text { Arm 2: Panobinostat } 20 \mathrm{mg} \text { po every } \\
\text { other week, TIW, } 3 \text { weeks on, I week } \\
\text { off + bevacizumab } 10 \mathrm{mg} / \mathrm{kg} \text { IV every } \\
\text { other week } \times 2 \text { (day I, day I5) } \\
\text { Arm 3: Panobinostat } 30 \mathrm{mg} \text { po every } \\
\text { other week, TIW, } 3 \text { weeks on, I week } \\
\text { off + bevacizumab I0 } \mathrm{mg} / \mathrm{kg} \text { IV every } \\
\text { other week } \times 2 \text { (day I, day I5) }\end{array}$ & $\begin{array}{l}3 \\
6\end{array}$ & $\begin{array}{l}3 \text { PR ( I in arm 2, } 2 \text { in arm 3), } \\
2 \text { PD ( I in arm I, I in arm 3), } \\
7 \text { SD; median OS } 8.2 \text { months }\end{array}$ & $\begin{array}{l}(\mathrm{n}=\text { I each): } \\
\text { thrombocytopenia, } \\
\text { hypophosphatemia, } \\
\text { esophageal hemorrhage, } \\
\text { deep venous thrombosis, } \\
\text { QTc prolongation, } \\
\text { lymphopenia }\end{array}$ & 36 \\
\hline $\begin{array}{l}\text { Castrate resistant } \\
\text { prostate cancer }\end{array}$ & Phase I & $\begin{array}{l}\text { Arm I: Panobinostat } 20 \mathrm{mg} \text { po three } \\
\text { times weekly, for } 2 \text { weeks, I week off, } \\
\text { every } 2 \text { I days } \\
\text { Arm 2: Panobinostat } 15 \mathrm{mg} \text { po three } \\
\text { times weekly for } 2 \text { weeks, I week off, } \\
\text { every } 2 \text { I days + docetaxel } 75 \mathrm{mg} / \mathrm{m}^{2} \mathrm{IV} \\
\text { every } 2 \text { I days + prednisone po } 10 \mathrm{mg} / \text { day }\end{array}$ & $\begin{array}{l}8 \\
8\end{array}$ & $\begin{array}{l}\text { Arm I: I SD } \\
\text { Arm 2: } 2 \text { PR (I with prior } \\
\text { taxane exposure) and } 4 \text { SD }\end{array}$ & $\begin{array}{l}\text { Arm I: }(n=I \text { each) } \\
\text { dyspnea, nausea, diarrhea } \\
\text { Arm 2: Fatigue }(n=2) \text {, } \\
\text { anemia }(n=I) \text {, leucopenia } \\
(n=2) \text {, neutropenia }(n=7) \text {, } \\
\text { hyperglycemia }(n=2)\end{array}$ & 25 \\
\hline $\begin{array}{l}\text { Castrate resistant } \\
\text { prostate cancer }\end{array}$ & Phase lb & $\begin{array}{l}\text { Cohort I: Panobinostat } 10 \mathrm{mg} / \mathrm{m}^{2} \mathrm{IV} \text { day I, } \\
8,15 \text { (out of } 2 \mathrm{I} \text { days) + docetaxel } 75 \mathrm{mg} / \mathrm{m}^{2} \\
\text { IV every } 2 \text { I days, + prednisone } 10 \mathrm{mg} / \text { day } \\
\text { Cohort } 2 \text { : Panobinostat } 15 \mathrm{mg} / \mathrm{m}^{2} \mathrm{IV} \text { day I, } \\
8,15 \text { (out of } 2 \text { I days) + docetaxel } \\
75 \mathrm{mg} / \mathrm{m}^{2} \text { IV every } 2 \text { I days, + prednisone } \\
10 \mathrm{mg} / \text { day } \\
\text { Cohort 3: Panobinostat } 20 \mathrm{mg} / \mathrm{m}^{2} \mathrm{IV} \text { day I, } 8 \text {, } \\
\text { I5 (out of } 2 \text { I days) + docetaxel } 75 \mathrm{mg} / \mathrm{m}^{2} \\
\text { IV every } 2 \text { I days, + prednisone } 10 \mathrm{mg} / \text { day }\end{array}$ & 22 & $\begin{array}{l}5 \text { patients with }>30 \% \text { decline } \\
\text { in PSA; } 4 \text { patients } \\
\text { with }>50 \% \text { decline in PSA }\end{array}$ & $\begin{array}{l}\text { Neutropenia }(n=12) \text {, } \\
\text { febrile neutropenia }(n=3) \text {, } \\
\text { bradycardia }(n=1) \text {, } \\
\text { dizziness }(n=2) \text {, } \\
\text { DVT }(n=1)\end{array}$ & 37 \\
\hline $\begin{array}{l}\text { Refractory } \\
\text { metastatic CRC }\end{array}$ & Phase II & $\begin{array}{l}\text { Panobinostat } 30 \mathrm{mg} \text { po TIW until disease } \\
\text { progression }\end{array}$ & 29 & $\begin{array}{l}3 \mathrm{SD} \text {, no objective responses, } \\
\text { TTP } 7.7 \text { weeks, median OS } \\
5.1 \text { months }\end{array}$ & Thrombocytopenia $(n=6)$ & 41 \\
\hline Metastatic HCC & $\begin{array}{l}\text { Case } \\
\text { report }\end{array}$ & $\begin{array}{l}\text { Sorafenib } 800 \text { mg po daily + panobinostat } \\
20 \mathrm{mg} \text { po day I, } 4 \text { ( } 2 \text { out of } 3 \text { weeks) }\end{array}$ & I & $\begin{array}{l}\text { Regression of liver and } \\
\text { skeletal metastases }\end{array}$ & $\mathrm{N} / \mathrm{A}$ & 45 \\
\hline Refractory GIST & Phase I & $\begin{array}{l}\text { Imatinib } 400 \mathrm{mg} \text { po daily + panobinostat } \\
20 \mathrm{mg}-30 \mathrm{mg} \text { po TIW ( } 3 \text { out of } 4 \text { weeks) }\end{array}$ & 12 & I PR, 7 SD, 3 PD & Thrombocytopenia $(n=2)$ & 48 \\
\hline $\begin{array}{l}\text { Advanced } \\
\text { pancreatic } \\
\text { cancer }\end{array}$ & Phase II & $\begin{array}{l}\text { Panobinostat } 20 \mathrm{mg} \text { TIW } \times \\
2 \text { weeks every } 21 \text { days }+ \\
\text { Bortezomib } 1.3 \mathrm{mg} / \mathrm{m}^{2} \text { twice weekly } \times \\
2 \text { weeks every } 21 \text { days }\end{array}$ & 7 & $\begin{array}{l}\text { Terminated early due to lack } \\
\text { of treatment responses and } \\
\text { unacceptable toxicity } \\
\text { Median PFS } 2.1 \text { months }\end{array}$ & $\begin{array}{l}\text { Grade } 3 \\
\text { thrombocytopenia (57\%) } \\
\text { Grade } 4 \text { diarrhea (29\%) }\end{array}$ & 51 \\
\hline $\begin{array}{l}\text { Medullary } \\
\text { thyroid cancer and } \\
\text { iodine refractory } \\
\text { thyroid cancer }\end{array}$ & Phase II & Panobinostat 20 mg po TIW & 13 & $\begin{array}{l}7 \mathrm{SD}, 6 \mathrm{PD} \text {, no objective } \\
\text { responses, median OS } \\
18.4 \text { months }\end{array}$ & Thrombocytopenia $(n=3)$ & 54 \\
\hline $\begin{array}{l}\text { Refractory } \\
\text { metastatic RCC }\end{array}$ & Phase II & Panobinostat $45 \mathrm{mg}$ po twice weekly & 12 & $\begin{array}{l}\text { No objective responses, all } \\
\text { patients with PD or } \\
\text { discontinued therapy }\end{array}$ & Reportedly well tolerated & 60 \\
\hline
\end{tabular}

Abbreviations: TIW, three times weekly; po, per oral; IV, intravenous; SD, stable disease; PD, progressive disease; PR, partial response; OS, overall survival; CRC, colorectal carcinoma; HCC, hepatocellular carcinoma; GIST, gastrointestinal stromal tumor; RCC, renal cell carcinoma; HER, human epidermal growth factor receptor; DVT, deep venous thrombosis; TTP, time to progression; PFS, progression free survival; AE, adverse event; Ref, reference; N/A, not available. 


\section{Lung cancer}

There has been considerable interest in studying panobinostat for the treatment of both non-small cell lung cancer (NSCLC) and small cell lung cancer (SCLC). In vivo studies using human NSCLC xenografts in a nude mouse model demonstrated that when panobinostat was combined with radiation, there was a growth delay of 20 days compared with 4 days with radiation alone or 2 days with panobinostat alone. ${ }^{31}$ This data suggests that panobinostat may be a useful adjunct as a radiation sensitizer in the treatment of NSCLC. ${ }^{32}$ Panobinostat has also been shown to be synergistic in combination with EGFR (epidermal growth factor receptor) inhibitors such as erlotinib in lung cancer cell lines that are dependent upon EGFR. ${ }^{33}$ Panobinostat allows acetylation of Hsp90, reducing its association with chaperone proteins, including EGFR, thereby triggering apoptosis in EGFRmutated cells. In this sense, future studies of panobinostat and NSCLC may focus on targeting tumors dependent on EGFR mutations. Trials of panobinostat in combination with standard cytotoxic therapy are also underway in patients with NSCLC.

Small cell lung cancer cell lines have also been shown to be highly sensitive to panobinostat. In vivo and in vitro models of 37 cell lines of all thoracic malignancies treated with panobinostat displayed the most potent antiproliferative activity and cytotoxicity in the SCLC cell lines. The SCLC cell lines displayed the most sensitivity to the drug, with the majority of cell lines showing $\mathrm{IC}_{50}<10 \mathrm{nmol} / \mathrm{L}$. $^{34}$ In a Phase II study of intravenous panobinostat in patients with progressive or relapsed small cell lung cancer, among 21 enrolled patients, two had tumor response of greater than $30 \%$, and three cases had stable disease (Table 4). ${ }^{35}$ Further studies with panobinostat in combination with chemotherapy are underway.

\section{CNS malignancy}

Responses with current chemotherapeutic and biologic therapies such as bevacizumab for high grade gliomas have not been shown to be durable. In this setting, the addition of panobinostat to bevacizumab has been studied. A Phase I study of twelve patients with recurrent high grade glioma were treated with panobinostat in two different schedules, in combination with bevacizumab. ${ }^{36}$ In this small sample study, three of the twelve patients achieved a radiographic partial response, two had progressive disease, and seven patients had stable disease, with an 8.2 month median overall survival from the date of registration (Table 3). ${ }^{36}$ Given the possibility of drug activity in high grade gliomas, and overall tolerability seen in the Phase I trial, there is now a Phase II study to further investigate this drug combination's efficacy and tolerability in patients with recurrent high grade gliomas.

\section{Prostate cancer}

A Phase I study of 16 patients with castration-resistant prostate cancer comparing oral panobinostat alone or in combination with docetaxel demonstrated that none of the patients in the panobinostat alone arm had a clinically significant disease response (Table 4). ${ }^{25}$ In the panobinostat plus docetaxel arm, two of the seven evaluable patients had a partial response, and an additional four patients had stable disease on imaging. In another Phase I study in 21 castrationresistant prostate cancer, intravenous panobinostat along with docetaxel in chemotherapy naïve patients demonstrated greater than 30\% decline in prostate specific antigen (PSA) in five patients and greater than $50 \%$ decline in PSA in four patients (Table 4). ${ }^{37}$ These results indicate that there may be a role for panobinostat in future therapy for prostate cancer treatments, although likely in combination with other drugs, given that disease activity with monotherapy was negligible. A Phase II trial of panobinostat in combination with bicalutamide is currently underway.

\section{Gastrointestinal cancers}

\section{Colon cancer}

In vitro studies have shown that panobinostat treatment of colon cancer cell lines inhibits proliferation and survival at nanomolar concentrations. Panobinostat has been shown to activate the tumor suppressor death-associated protein kinase (DAPK), which plays a role in induction of autophagy and apoptosis. ${ }^{38}$ Analysis of gene expression profiles of colorectal cancer (CRC) cell lines treated with panobinostat revealed that only $5 \%-7 \%$ of genes were altered. These selective genes regulate cellular processes such as angiogenesis, mitosis, DNA replication, and apoptosis. ${ }^{39}$

In preclinical studies by LaBonte et al, ${ }^{40}$ after treatment with panobinostat, all CRC cell lines tested showed concentration-dependent growth inhibitory activity with IC50 values from $5.5-25.9 \mu \mathrm{mol} / \mathrm{L}$. Furthermore, simultaneous treatment with lapatinib, an EGFR/HER2 kinase inhibitor, resulted in a synergistic inhibition in growth (Table 3). This drug combination was found to decrease protein expression of EGFR and HER2. ${ }^{40}$ These results may warrant further clinical investigation with panobinostat, alone and in combination with drugs such as lapatinib, for treatment in colorectal carcinoma. 
A Phase II study of panobinostat in patients with refractory metastatic CRC (median of three prior therapies) was performed (Table 4). Results from 29 patients showed three patients with stable disease, without any objective responses. The time to progression was 7.7 weeks, with a median overall survival time of 5.1 months. ${ }^{41}$

\section{Hepatocellular carcinoma}

A novel mechanism of apoptosis involving the endoplasmic reticulum stress pathway has been described in hepatocellular cancer $(\mathrm{HCC})$ cell lines treated with panobinostat. ${ }^{42}$ Panobinostat has been demonstrated to induce cellular unfolded protein response and upregulate pro-apoptotic factors, which ultimately leads to activation of caspases and to apoptosis. ${ }^{43}$

Inactivation of tumor suppressor genes like the Rasassociated domain family 1 isoform A (RASSF1A) and adenomatous polyposis coli (APC), and overexpression of DNA methyltransferases (DNMT), have previously been shown to be common in $\mathrm{HCC}$ and have been linked to malignant potential and poor prognosis. ${ }^{44}$ Cell lines treated with panobinostat have demonstrated inhibition of DNMT as well as diminished methylation of RASSF1 A and decreased expression of APC. ${ }^{44}$ Other studies in HCC cell lines and a xenograft model have shown that panobinostat can inhibit proliferation pathways via upregulation of $\mathrm{p} 21$, an endogenous cell cycle inhibitor. ${ }^{45}$

Furthermore, panobinostat has shown to inhibit mitogenactivated protein kinase (MAPK) activity. MAPK is the final downstream target of receptor tyrosine kinases and the Ras-Raf signaling pathway, which is the main target of sorafenib. ${ }^{45}$ Such information provides rationale for combination therapy and a basis for possible additive effects between these two drug classes.

Lachenmayer et $\mathrm{al}^{46}$ have shown that use of panobinostat in several liver cancer cell lines leads to in vitro and in vivo antitumor effects, which were found to be enhanced with the addition of sorafenib. In several human HCC cell lines cultured with panobinostat, cell viability and proliferation declined in a time- and dose-dependent manner, and apoptosis, as well as autophagy, increased. ${ }^{46}$ Cell lines cultured with panobinostat experienced reduced tumor volumes as compared with controls. When sorafenib was added to the regimen, researchers found decreased vessel density and further decreased tumor volume, as well as increased survival (Table 4). ${ }^{46}$

One case report of a patient with metastatic $\mathrm{HCC}$ demonstrates response to treatment with sorafenib and panobinostat. ${ }^{45}$ The report describes a 68 -year-old male with metastatic multilocular HCC initially treated with sorafenib at $800 \mathrm{mg}$ daily, who showed a mixed radiographic response on MRI 6 weeks after treatment. The patient was subsequently started on panobinostat at a dose of $20 \mathrm{mg}$ in addition to daily sorafenib. After eight cycles, there was evidence of regression of liver and skeletal metastases lesions (Table 4). ${ }^{45}$

\section{Gastrointestinal stromal tumors}

In an experimental study by Floris et al, ${ }^{47} 36$ mice, each bearing two gastrointestinal stromal tumor (GIST) xenografts, were assigned to four treatment groups: no-treatment, panobinostat, imatinib, and a panobinostat-imatinib combination. While the tumors in the no-treatment group continued to grow from baseline, the tumors in the panobinostat group shrunk by $25 \%$, and tumors in the combination therapy group shrank by $73 \%$ at 12 days (Table 3 ). Notably, responses were seen even in xenografts with the kit-exon 9 mutation, which is known for resistance to imatinib. This early study suggests the potential therapeutic activity of panobinostat in human GIST. Results from a Phase I doseescalating trial of 12 patients with refractory GIST (median five prior therapies) treated with a combination of imatinib and panobinostat are summarized in Table $4 .{ }^{48}$

\section{Gastric carcinoma}

Preclinical data suggests that further study of panobinostat as therapy in gastric cancer may be useful as adjunct to other chemotherapies, such as anthracyclines. ${ }^{49}$ Microarray analysis of mRNA (messenger RNA) isolates from gastric cancer cell lines found that several genes indicative of doxorubicin resistance were down regulated after treatment with panobinostat. It was also shown that panobinostat downregulated expression of genes that mediate anthracycline resistance via activation of CITED2 ( $\mathrm{Cbp} / \mathrm{p} 300$-interacting transactivator 2), a gene that mediates cell sensitivity to chemotherapeutics such as anthracyclines. ${ }^{49}$ Future study in this area may therefore focus on the use of panobinostat as a chemosensitizing agent for use along with anthracyclines, which constitute the backbone of many of the chemotherapy regimens for gastric cancer.

\section{Pancreatic cancer}

One study investigating panobinostat and BEZ235, a PI3K (phosphatidylinositide 3-kinase) and mTOR (mammalian target of rapamycin) inhibitor, suggests that there may be activity with these drugs alone, and also in combination, against pancreatic cancer. ${ }^{50}$ Treatment with BEZ235 or 
panobinostat inhibited cell cycle progression via induction of the cell cycle inhibitory proteins p21 and p27. BEZ235 and panobinostat were also found to dose-dependently induce the loss of cell viability in cultured pancreatic ductal adenocarcinoma cells. Co-treatment with both drugs also displayed a significant reduction in growth of cells in xenograft models of pancreatic ductal adenocarcinoma in nude mice. ${ }^{50}$

A Phase II study in advanced pancreatic cancer patients who had progressed on gemcitabine-based therapy was performed using a combination of panobinostat along with bortezomib. ${ }^{51}$ The study was suspended because of lack of treatment responses and unacceptable early toxicity (Table 4).

\section{Head and neck cancer}

Thyroid cancer

In preclinical studies of anaplastic thyroid cancer cell lines, panobinostat has been found to induce G1 cell cycle arrest at low concentrations. ${ }^{52}$ In vivo, mice models of anaplastic thyroid cancer treated with $20 \mathrm{mg} / \mathrm{kg}$ of panobinostat displayed higher levels of apoptotic nuclei and decreased levels of Ki67 as compared with controls (Table 3). ${ }^{52}$ Other studies have examined anaplastic thyroid cancer cells and E-cadherin levels. ${ }^{53}$ E-cadherin is a protein that typically functions in the role of epithelial cell-cell adhesion and has been shown to prevent tumor invasion. This protein is found in high levels in normal thyroid tissue and at reduced or absent levels in anaplastic thyroid cancer. After culture of three anaplastic thyroid cancer cell lines with panobinostat, E-cadherin expression was found to be induced, leading to impaired cancer cell migration and invasion. ${ }^{53}$ These results suggest that further studies with panobinostat in anaplastic thyroid cancer are warranted.

Panobinostat is also being studied in differentiated thyroid cancers. Results from a Phase II trial of panobinostat in medullary thyroid cancer and iodine refractory differentiated thyroid cancer are summarized in Table $4 .{ }^{54}$

\section{Squamous cell cancer}

Panobinostat has also been studied in squamous cell cancer of the head and neck (SCCHN) and has been found to cause up regulation of $\mathrm{p} 21, \mathrm{G} 2 / \mathrm{M}$ cell cycle arrest and cell death of cell lines. ${ }^{55}$ When gene expression profiles of 41 SCCHN samples were examined, many of the genes required for DNA replication, repair, and growth arrest that have increased expression in SCCHN were down regulated by panobinostat, suggesting that this malignancy may respond to treatment with panobinostat. ${ }^{55}$
Panobinostat was tested either alone or in combination with dual PI3K-mTOR inhibitors, BEZ235, BGT226, and the PI3K inhibitor BKM120 in SCCHN cell lines. ${ }^{56}$ AKT (also known as protein kinase $\mathrm{B}$ ) activation has been shown to be an early event in SCCHN progression and panobinostat has been shown to induce a persistent inhibition of AKT. Additionally, the combination of panobinostat to any of the above drugs caused additional inhibition of AKT as compared with drug monotherapy. ${ }^{56}$

Reduced tumor growth rates have been demonstrated in xenograft models treated with the above drugs (BEZ235, BGT226, BKM120) alone or in combination with panobinostat. However, treatment with BEZ235, BGT226, or BKM120 proved to be more effective than treatment with panobinostat alone. Furthermore, addition of panobinostat to any of the above drug therapies did not lead to greater tumor response as compared to treatment with drug monotherapy (Table 3). ${ }^{56}$ These varying results suggest that further investigation of the use of panobinostat as adjunct therapy for SCCHN is needed.

\section{Ovarian cancer}

Observations in preclinical studies using several human ovarian cancer cell lines have identified panobinostat to have synergistic effects with drugs commonly used to treat ovarian cancer, such as gemcitabine, paclitaxel, docetaxel, and 5'-DFUR (metabolite of capecitabine). ${ }^{57,58}$ Additionally, the treatment of panobinostat in combination with cisplatin of ovarian cancer previously resistant to cisplatin may be a viable treatment option based upon preclinical data showing that the presence of panobinostat lowered the inhibitory concentration for cisplatin in previously cisplatin resistant ovarian cancer cell lines. ${ }^{59}$

\section{Renal cell carcinoma}

Panobinostat has not been shown to be promising in renal cell carcinoma (RCC). There was one patient with metastatic RCC treated as part of a Phase I study, who experienced a confirmed partial response, and remained on the drug for more than 2 years. ${ }^{16}$ However, a Phase II trial of panobinostat in 20 refractory RCC patients previously treated with an angiogenesis inhibitor and an mTOR inhibitor showed no activity, with all patients either progressing or stopping treatment prior to the 16-week evaluation period (Table 4). ${ }^{60}$ Phase I trials are underway studying panobinostat in combination with sorafenib or everolimus in advanced RCC.

\section{Conclusion}

The biology of epigenetics has emerged as important in development of malignancies. While the histone protein is 
one major substrate in which HDAC enzymes act, HDAC proteins have also been shown to modulate cancer cell growth via non histone protein targets, including transcription factors, growth factors, and molecular chaperones. HDAC inhibitors have been studied for the treatment of hematologic malignancies as well as solid tumors. In addition to single agent activity, HDAC inhibitors have been shown to be synergistic with cytotoxic therapy by means of their inhibition of DNA repair and synthesis. Panobinostat is a novel pan-HDAC inhibitor which has shown greater inhibitory potential than the currently FDA approved HDAC inhibitors. Data from Phase I and Phase II studies have demonstrated that it is well tolerated with minimal toxicity. Studies are underway to evaluate its efficacy in specific solid tumor types as well as to identify appropriate synergistic cytotoxic, biologic and small molecule inhibitor combinations.

\section{Disclosure}

The authors report no conflicts of interest in this work.

\section{References}

1. Ropero S, Esteller M. The role of histone deacetylases (HDACs) in human cancer. Mol Oncol. 2007;1(1):19-25.

2. Dawson MA, Kouzarides T. Cancer epigenetics: from mechanism to therapy. Cell. 2012;150(1):12-27.

3. Atadja P. Development of the pan-DAC inhibitor panobinostat (LBH589): successes and challenges. Cancer Lett. 2009;280(2):233-241.

4. Prince HM, Bishton M. Panobinostat (LBH589): a novel pandeacetylase inhibitor with activity in T cell lymphoma. Hematology Meeting Reports. 2009;3(1):33-38.

5. Kouzarides T. Histone acetylases and deacetylases in cell proliferation. Curr Opin Genet Dev. 1999;9(1):40-48.

6. Marks PA, Xu WS. Histone deacetylase inhibitors: Potential in cancer therapy. J Cell Biochem. 2009;107(4):600-608.

7. Bali P, Pranpat M, Bradner J, et al. Inhibition of histone deacetylase 6 acetylates and disrupts the chaperone function of heat shock protein 90: a novel basis for antileukemia activity of histone deacetylase inhibitors. J Biol Chem. 2005;280(29): 26729-26734.

8. Rodriguez-Gonzalez A, Lin T, Ikeda AK, Simms-Waldrip T, Fu C, Sakamoto KM. Role of the aggresome pathway in cancer: targeting histone deacetylase 6-dependent protein degradation. Cancer Res. 2008;68(8):2557-2560.

9. New M, Olzscha H, Liu G, et al. A regulatory circuit that involves HR23B and HDAC6 governs the biological response to HDAC inhibitors. Cell Death Differ. Epub May 24, 2013.

10. Khan O, Fotheringham S, Wood V, et al. HR23B is a biomarker for tumor sensitivity to HDAC inhibitor-based therapy. Proc Natl Acad Sci U S A. 2010;107(14):6532-6537.

11. Dickinson M, Johnstone RW, Prince HM. Histone deacetylase inhibitors: potential targets responsible for their anti-cancer effect. Invest New Drugs. 2010;28(Suppl 1):S3-S20.

12. Minucci S, Pelicci PG. Histone deacetylase inhibitors and the promise of epigenetic (and more) treatments for cancer. Nat Rev Cancer. 2006;6(1):38-51.

13. Kauh J, Fan S, Xia M, Yue P, Khuri FR, Sun SY. c-FLIP degradation mediates sensitization of pancreatic cancer cells to TRAIL-induced apoptosis by the histone deacetylase inhibitor LBH589. PLoS One. 2010;5(4):e10376.
14. Savelieva M, Woo MM, Weber HA, et al. Population pharmacokinetics of panobinostat (LBH589) in patients with advanced solid tumors and hematologic malignancies following intravenous and oral administration. Poster presented at: American Society of Hematology, December 7, 2009, New Orleans, LA, USA.

15. Clive S, Woo MM, Nydam T, Kelly L, Squier M, Kaqan M. Characterizing the disposition, metabolism, and excretion of an orally active pan-deacetylase inhibitor, panobinostat, via trace radiolabeled 14C material in advanced cancer patients. Cancer Chemother Pharmacol. 2012;70(4):513-522.

16. Shapiro GI, Frank R, Dandamudi UB, et al. The effect of food on the bioavailability of panobinostat, an orally active pan-histone deacetylase inhibitor, in patients with advanced cancer. Cancer Chemother Pharmacol. 69(2):555-562.

17. Hamberg P, Woo MM, Chen LC, et al. Effect of ketoconazole-mediated CYP3A4 inhibition on clinical pharmacokinetics of panobinostat (LBH589), an orally active histone deacetylase inhibitor. Cancer Chemother Pharmacol. 2011;68(3):805-813.

18. Sharma S, Voest E, Hagner N, et al. Effects of renal function on the pharmacokinetics of panobinostat in patients with advanced cancer: a Phase I study. Blood. 2011;118:5001.

19. Prince HM, Bishton MJ, Harrison SJ. Clinical studies of histone deacetylase inhibitors. Clin Cancer Res. 2009;15(12):3958-3969.

20. Lin RH, Jing H, Paul S, et al. Characteristics of thrombocytopenia in patients treated with oral panobinostat (LBH589). Poster 2740 presented at: American Society of Hematology, December 6, 2009, New Orleans, LA, USA.

21. Sharma S, Vogelzang NJ, Beck J, et al. Phase I pharmacokinetic (PK) and pharmacodynamic (PD) study of LBH589, a novel deacetylase (DAC) inhibitor given intravenously on a new once weekly schedule. J Clin Oncol. 2007;25(18S):14019.

22. Deangelo DJ, Spencer A, Bhalla KN, et al. Phase Ia/II, two-arm, openlabel, dose-escalation study of oral panobinostat administered via two dosing schedules in patients with advanced hematologic malignancies. Leukemia. 2013;27(8):1628-1636.

23. Prince HM, George D, Patnaik A, et al. Phase I study of oral LBH589, a novel deacetylase (DAC) inhibitor in advanced solid tumors and non-hodgkin's lymphoma. J Clin Oncol (2007 ASCO Annual Meeting Proceedings; Post-Meeting Edition). 2007;25(18S):3500.

24. Fukutomi A, Hatake K, Matsui K, et al. A phase I study of oral panobinostat (LBH589) in Japanese patients with advanced solid tumors. Invest New Drugs. 2012;30(3):1096-1106.

25. Rathkopf D, Wong BY, Ross RW, et al. A phase I study of oral panobinostat alone and in combination with docetaxel in patients with castration-resistant prostate cancer. Cancer Chemother Pharmacol. 2010;66(1):181-189.

26. Tate CR, Rhodes LV, Segar HC, et al. Targeting triple-negative breast cancer cells with the histone deacetylase inhibitor panobinostat. Breast Cancer Res. 2012;14(3):R79.

27. Rao R, Balusu R, Fiskus W, et al. Combination of pan-histone deacetylase inhibitor and autophagy inhibitor exerts superior efficacy against triple-negative human breast cancer cells. Mol Cancer Ther. 2012;11(4): 973-983.

28. Budman DR, Calabro A, Rosen L, Lesser M. Identification of unique synergistic drug combinations associated with downexpression of survivin in a preclinical breast cancer model system. Anticancer Drugs. 2012;23(3):272-279.

29. Conte P, Campone M, Pronzato D, et al. Phase I trial of panobinostat (LBH589) in combination with trastuzumab in pretreated HER2-positive metastatic breast cancer $(\mathrm{mBC})$ : Preliminary safety and tolerability results. J Clin Oncol. 2009;27(15s):1081.

30. Tan W, Allred JB, Moreno-Aspitia A, et al. Phase I study of panobinostat (LBH589) and letrozole in post-menopausal women with metastatic breast cancer. J Clin Oncol. 2012;30:e13501.

31. Gridelli C, Rossi A, Maione P. The potential role of histone deacetylase inhibitors in the treatment of non-small-cell lung cancer. Crit Rev Oncol Hematol. 2008;68(1):29-36. 
32. Geng L, Cuneo KC, Fu A, Tu T, Atadja PW, Hallahan DE. Histone deacetylase (HDAC) inhibitor LBH589 increases duration of gamma$\mathrm{H} 2 \mathrm{AX}$ foci and confines HDAC4 to the cytoplasm in irradiated nonsmall cell lung cancer. Cancer Res. 2006;66(23):11298-11304.

33. Edwards A, Li J, Atadja P, Bhalla K, Haura EB. Effect of the histone deacetylase inhibitor LBH589 against epidermal growth factor receptor-dependent human lung cancer cells. Mol Cancer Ther. 2007;6(9):2515-2524.

34. Crisanti MC, Wallace AF, Kapoor V, et al. The HDAC inhibitor panobinostat (LBH589) inhibits mesothelioma and lung cancer cells in vitro and in vivo with particular efficacy for small cell lung cancer. Mol Cancer Ther. 2009;8(8):2221-2231.

35. De Marines F, Atmaca A, Tiseo M, et al. Deacetylase inhibitor (DACI) panobinostat in relapsed small cell lung cancer (SCLC) patients: results of a multicenter phase II trial. J Clin Oncol. 2010;28:e17521.

36. Drappatz J, Lee EQ, Hammond S, et al. Phase I study of panobinostat in combination with bevacizumab for recurrent high-grade glioma. J Neurooncol. 2012;107(1):133-138.

37. Rathkopf DE, Chi KN, Vaishampayan U, et al. Phase Ib dose finding trial of intravenous panobinostat with docetaxel in patients with castrationresistant prostate cancer (CRPC). J Clin Oncol. 2009; 27(15S):5064.

38. Gandesiri M, Chakilam S, Ivanovska J, Benderska N, Ocker M, Di Fazio P. DAPK plays an important role in panobinostat-induced autophagy and commits cells to apoptosis under autophagy deficient conditions. Apoptosis. 2012;17(12):1300-1315

39. LaBonte MJ, Wilson PM, Fazzone W, Groshen S, Lenz HJ, Ladner RD. DNA microarray profiling of genes differentially regulated by the histone deacetylase inhibitors vorinostat and LBH589 in colon cancer cell lines. BMC Med Genomics. 2009;2(67):3825-3648.

40. LaBonte MJ, Wilson PM, Fazzone W, et al. The dual EGFR/HER2 inhibitor lapatinib synergistically enhances the antitumor activity of the histone deacetylase inhibitor panobinostat in colorectal cancer models. Cancer Res. 2011;71(10):3635-3648.

41. Gold PJ, Smith DA, Iriarte D, Boatman B, Kaplan HG. Phase II trial of panobinostat (LBH589) in patients (pts) with refractory metastatic colorectal cancer (MCRC). J Clin Oncol. 2012;30(Suppl 4):582.

42. Di Fazio P, Schneider-Stock R, Neureiter D, et al. The pan-deacetylase inhibitor panobinostat inhibits growth of hepatocellular carcinoma models by alternative pathways of apoptosis. Cell Oncol. 2010;32(4): 285-300.

43. Montalbano R, Waldegger P, Quint K, et al. Endoplasmic reticulum stress plays a pivotal role in cell death mediated by the pan-deacetylase inhibitor panobinostat in human hepatocellular cancer cells. Transl Oncol. 2013;6(2):143-157.

44. Zopf S, Ocker M, Neureiter D, et al. Inhibition of DNA methyltransferase activity and expression by treatment with the pan-deacetylase inhibitor panobinostat in hepatocellular carcinoma cell lines. BMC Cancer. 2012;12:386.

45. Gahr S, Wissniowski T, Zopf S, Strobel D, Pustowka A, Ocker M. Combination of the deacetylase inhibitor panobinostat and the multikinase inhibitor sorafenib for the treatment of metastatic hepatocellular carcinoma - review of the underlying molecular mechanisms and first case report. J Cancer. 2012;3:158-165.

46. Lachenmayer A, Toffanin S, Cabellos L, et al. Combination therapy for hepatocellular carcinoma: additive preclinical efficacy of the HDAC inhibitor panobinostat with sorafenib. $J$ Hepatol. 2012;56(6): $1343-1350$.

OncoTargets and Therapy

\section{Publish your work in this journal}

OncoTargets and Therapy is an international, peer-reviewed, open access journal focusing on the pathological basis of all cancers, potential targets for therapy and treatment protocols employed to improve the management of cancer patients. The journal also focuses on the impact of management programs and new therapeutic agents and protocols on
47. Floris G, Debeic-Rychter M, Sciot R, et al. High efficacy of panobinostat towards human gastrointestinal stromal tumors in a xenograft mouse model. Clin Cancer Res. 2009;15(12):4066-4076.

48. Bauer S, Hilger RA, Grabellus F, et al. Phase I trial of panobinostat (P) and imatinib (IM) in patients with treatment-refractory gastrointestinal stromal tumors (GIST). Poster presented at: 2012 ASCO Annual Meeting; Chicago, IL, May 31-June 4, 2012. J Clin Oncol. 2012;30:e10032.

49. Regel I, Merkl L, Friedrich T, et al. Pan-histone deacetylase inhibitor panobinostat sensitizes gastric cancer cells to anthracyclines via induction of CITED. Gastroenterology. 2012;143(1):99-109. e10.

50. Venkannagari S, Fiskus W, Peth K, et al. Superior efficacy of cotreatment with dual PI3K/mTOR inhibitor NVP-BEZ235 and pan-histone deacetylase inhibitor against human pancreatic cancer. Oncotarget. 2012;3(11):1416-1427.

51. Wang H, Cao Q, Dudek AZ. Phase II study of panobinostat and bortezomib in patients with pancreatic cancer progressing on gemcitabine-based therapy. Anticancer Res. 2012;32(3):1027-1031.

52. Catalano MG, Pugliese M, Gargantini E, et al. Cytotoxic activity of the histone deacetylase inhibitor panobinostat (LBH589) in anaplastic thyroid cancer in vitro and in vivo. Int $J$ Cancer. 2012;130(3): 694-704.

53. Catalano MG, Fortunati N, Pugliese M, et al. Histone deacetylase inhibition modulates E-cadherin expression and suppresses migration and invasion of anaplastic thyroid cancer cells. J Clin Endocrinol Metab. 2012;97(7):E1150-E1159.

54. Traynor AM, Leverson GE, Elson DF, et al. Panobinostat, a novel histone deacetylase inhibitor, in advanced medullary and iodine-refractory differentiated thyroid cancer: A Wisconsin Oncology Network trial. J Clin Oncol. 2013;31:e17025.

55. Prystowsky MB, Adomako A, Smith RV, et al. The histone deacetylase inhibitor LBH589 inhibits expression of mitotic genes causing G2/M arrest and cell death in head and neck squamous cell carcinoma cell lines. J Pathol. 2009;218(4):467-477.

56. Erlich RB, Kherrouche Z, Rickwood D, et al. Preclinical evaluation of dual PI3K-mTOR inhibitors and histone deacetylase inhibitors in head and neck squamous cell carcinoma. Br J Cancer. 2012;106(1): $107-115$.

57. Budman DR, Tai J, Calabro A, John V. The histone deacetylase inhibitor panobinostat demonstrates marked synergy with conventional chemotherapeutic agents in human ovarian cancer cell lines. Invest New Drugs. 2011;29(6):1224-1229.

58. Chao H, Wang L, Hao J, et al. Low dose histone deacetylase inhibitor, LBH589, potentiates anticancer effect of docetaxel in epithelial ovarian cancer via PI3K/Akt pathway in vitro. Cancer Let. 2013;329(1): $17-26$.

59. MaYY, Lin H, Moh JS, et al. Low-dose LBH589 increases the sensitivity of cisplatin to cisplatin-resistant ovarian cancer cells. Taiwan J Obstet Gynecol. 2011;50(2):165-171.

60. Hainsworth JD, Infante JR, Spigel DR, Arrowsmith ER, Boccia RV, Burris HA. A phase II trial of panobinostat, a histone deacetylase inhibitor, in the treatment of patients with refractory metastatic renal cell carcinoma. Cancer Invest. 2011;29(7):451-455. patient perspectives such as quality of life, adherence and satisfaction The manuscript management system is completely online and includes a very quick and fair peer-review system, which is all easy to use. Visit http://www.dovepress.com/testimonials.php to read real quotes from published authors. 